\title{
PENGEMBANGAN SISTEM DOKUMENTASI KEPERAWATAN DALAM MENINGKATKAN KUALITAS PELAYANAN KESEHATAN
}

\section{Khairun nisa ginting}

\author{
Kahirunnisaginting@gmail.com
}

\section{LATAR BELAKANG}

Dunia keperawatan di Indonesia terus berkembang pesat, kemajuan teknologi informasi dan komunikasi dalam bidang kesehatan menyebabkan akses informasi yang sangat cepat di seluruh dunia. Hal itu membawa dampak pada kemajuan yang cukup berarti dalam bidang keperawatan. Salah satunya sistem catatan keperawatan dari yang sebelumnya manual, bergeser menjadi komputerisasi.

Dokumentasi keperawatan merupakan bagian integral dari asuhan keperawatan, dokumentasi keperawatan merupakan salah satu fungsi yang paling penting dari perawat. Disini ditulis segala informasi tentang klien sehingga dapat memberikan asuhan keperawatan yang sesuai dengan kebutuhan klien. Melalui dokumentasi perawat dapat memutuskan tindakan yang tepat untuk klien. Keakuratan suatu data data klien dalam proses keperawatan di era modern saat ini menjadi tuntutan dari berbagai aspek bagi para perawat, bermacam macam bentuk, upaya telah dilakukan selama bertahun-tahun untuk meningkatkan dokumentasi keperawatan, hal ini dilakukan dalam upaya untuk meningkatkan kualitas pelayanan perawatan klien (Paan et al, 2010).

Sebuah keprihatinan bersama mengenai dokumentasi keperawatan adalah catatan mengenai pengkajian yang tidak aktual, intervensi, implementasi serta evaluasi keperawatan yang tidak konsisten dan tidak lengkap sehingga tidak memenuhi standar asuhan keperawatan. Disamping itu masih banyak perawat yang tidak tahu data apa yang harus dimasukkan dan bagaimana dokumentasi keperawatan yang benar, untuk itu perlu adanya inovasi pencatatan dengan menggunakan pencatatan berbasis elektronik. Pencatatan berbasis elektronik telah lebih 
dahulu dilakukan oleh negara negara maju, namun di Indonesia baru dilakukan pada tahun 2000an.

Dalam hal ini catatan keperawatan tidak mendukung sebagai informasi yang dapat dipertanggungjawabkan dalam hukum (Chand, 2014). Perkembangan saat ini bahwa perawat harus melakukan proses keperawatan berdasarkan standar asuhan keperawatan. (Hickey et al, 2012). Smith et al (2005) mengatkan bahwa Ini tidak berjalan dengan baik dikarenakan dokumentasi keperawatan dilakukan secara manual, data direkam menggunakan tulisan atau direkam dalam bentuk grafik. Dan dokumentasi ini memungkinkan tidak terbaca oleh tim kesehatan lain, meskipun mungkin berisi informasi yang penting. Ini tidak dapat meningkatkan pertukaran informasi dan koordinasi baik antar perawat maupun tim kesehatan lainya.

Catatan keperawatan berbasis elektronik diharapkan dapat meningkatkan kualitas perawatan yang diberikan kepada pasien yang dirawat di rumah sakit. Bagi perawat, penggunaan sumber dokumentasi elektronik menjadi sangat relevan karena di sinilah perawat memperoleh dan menuangkan sebanyak mungkin informasi pasien yang sesuai kebutuhan. Dalam organisasi layanan kesehatan, dokter dan perawat adalah penyedia layanan utama yang mendapat manfaat secara langsung atau tidak langsung dari sistem pendokumentasian elektronik selain dari pasien. Para ahli kesehatan telah mengakui bahwa kemampuan perawat dan dokter untuk memanfaatkan pendokumentasian elektronik secara signifikan sangat efektif dalam perawatan pasien dan meningkatkan kesejahteraan pasien, mengurangi biaya untuk pelatihan dan mengurangi pengeluaran perawatan kesehatan, Namun, perawat memerlukan keterampilan dan pengetahuan untuk menggunakan pendokumentasian elektronik secara efektif, mereka mendapatkan pengetahuan melalui pelatihan dan pelatihan kerja (Powell-Cope, Nelson \& Patterson 2008, 50 dalam Kamau, Nancy, 2015).

Saat ini teknologi telah berkembang pesat, begitu pula dengan teknologi yang dikembangkan untuk dapat mendukung kinerja keperawatan dalam hal dokumentasi yang berbentuk sistem dokumentasi keperawatan secara elektronik. Aplikasi ini berbasis teknologi IT yang akan mendukung dalam pencatatan serta pendokumentasian keperawatan terhadap suatu kasus pada klien. Seperti halnya negara-negara eropa yang telah megembangkan teknologi untuk meningkatkan sistem pendokumentasian yang merupakan metode sistematis. Dokumentasi 
keperawatan yang telah ditujukan untuk meningkatkan catatan klien dan mempertahankan kualitas asuhan keperawatan (Lovlien et al, 2007).

Dokumentasi keperawatan berbasis elektronik ini memberikan keuntungan bagi perawat dalam hal waktu pendokumentasian yang lebih singkat, keterbacaan data dan kemudahan akses bila dibandingkan dokumentasi dalam format kertas. Pengembangan dokumentasi keperawatan berbasis elektronik tetap harus memperhatikan prinsip kerahasiaan data klien, komprehensif, akurat, tepat waktu, dan jelas mengidentifikasi pemberi perawatan sehingga perlu adanya kebijakan dan pedoman yang jelas bagi tenaga perawat dalam menjalankan sistem ini.

\section{METODE}

Penelitian ini menggunakan metode penelitian kualitatif fenomenologi dengan pengumpulan data melalui wawancara dan double check. serta Literature review dengan cara menganalisis, kajian dan eksplorasi jurnal, text book, maupun e-book yang relevan dan membahas evaluasi asuhan keperawatan pada pasien baru. Adapun jurnal yang digunakan pada literature review ini adalah jurnal yang diterbitkan dari kurun waktu 10 tahun terakhir didapatkan dengan menggunakan 2 database Portal Garuda dan Google Scholar.

\section{HASIL}

Dari SURYA Vol. 11, No. 03, dampak positif dari penerapan sistem pencatatan keperawatan elektronik ini dapat meningkatkan kualitas asuhan keperawatan dan efisiensi serta keamanan data pasien. Untuk itu, diperlukan dukungan manajer dan keterlibatan perawat dalam pengembangan sistem, dengan harapan menumbuhkan keinginan perawat untuk terus menggunakan sistem ini. Oleh karena itu, hasil telaah literatur ini dapat menjadi dasar bagi pembuat kebijakan dalam menentukan langkah penerapan, dan pengembangan desain sistem pencatatan keperawatan elektronik pada pelayanan kesehatan untuk meningkatkan kualitas mutu pelayanan dan keselamatan pasien. 
Dari Dyah Fitri Wulandari, Pengembangan Dokumentasi Keperawatan Dokumentasi keperawatan yang berlaku di rumah sakit saat ini umumnya dilakukan secara tertulis (paper based documentation). Metode ini mempunyai kelemahan yaitu memerlukan waktu yang cukup lama untuk mengisi form yang tersedia, membutuhkam biaya percetakan form yang cukup mahal, sering hilang atau terselip, memerlukan tempat penyimpanan yang luas dan menyulitkan pencarian kembali saat diperlukan. Diperlukan inovasi dokumentasi keperawatan dengan menggunakan dokumentasi berbasis elektronik. Dokumentasi keperawatan berbasis elektronik ini memberikan keuntungan bagi perawat dalam hal waktu pendokumentasian yang lebih singkat, keterbacaan data dan kemudahan akses bila dibandingkan dokumentasi dalam format kertas.

Dari 500 Jurnal Kesehatan, Volume 9, Nomor 3, November 2018, Dokumentasi keperawatan yang berbasis teknologi IT sangat diperlukan di era modern saat ini disamping dapat memberikan keakuratan data kepada klien serta perencanaan untuk megahasilkan kualitas dan kinerja perawat dalam melakukan asuhan keperawatan yang baik. Sebagai pelaksana pelayanan kesehatan, rumah sakit juga sangat terbantu dengan adanya sistem dokumentasi keperawatan secara elektronik karena dapat menyediakan akses yang cepat dalam memberikan informasi, meminimalkan potensi kehilangan atau informasi yang rusak, menekan anggaran biaya yang dikeluarkan. Dapat mengurangi resiko kesalahan dalam melakukan intervensi, membantu dalam memenuhi pertanggungjawaban dokumentasi melalui akurasi informasi dan data pasien, memudahkan data epidemiologi, meningkatkan komunikasi dalam pertukaran informasi serta koordinasi diantara perawat dan anggota tim kesehatan lainya,meningkatkan keselamatan pasien dengan mengurangi kesalahan medis (John et al, 2016).

\section{PEMBAHASAN}

Dokumentasi adalah rekaman tertulis dan hukum dari intervensi yang menyangkut pasien dan itu mencakup serangkaian proses. Dokumentasi dibuat dengan catatan pribadi pasien, yang merupakan basis informasi tentang situasi kesehatannya. Pentingnya dokumentasi keperawatan adalah neuralgik, asalkan tanpa itu, tidak akan ada intervensi keperawatan kualitatif lengkap dan bahkan tidak ada perawatan yang efektif untuk pasien. Dalam tujuan dokumentasi keperawatan termasuk penelitian tentang perawatan yang lebih efektif dari masalah yang sudah terdeteksi, 
pemrograman perawatan melalui organisasi dan modifikasi rencana perawatan pasien dan komunikasi yang lebih langsung antara para profesional dari sistem kesehatan, yang berkolaborasi dalam perawatan pasien.

Terlepas dari sistem dokumentasi yang digunakan oleh suatu institusi, perawat mendaftar secara terus-menerus berbagai bukti aktivitas keperawatan, selama durasi manfaat perawatan. Pendokumentasian elektronik merupakan sistem pencatatan berbasis komputer yeng merekam aktifitas yang dilakukan oleh perawat dalam aktivitas keperawatan, yaitu pendokumentasian asuhan keperawatan. Catatan kesehatan elektronik adalah sekumpulan data yang menggambarkan perkembangan tentang kondisi kesehatan seseorang (Weaver et al., 2016).

Manfaat yang terkait dengan catatan kesehatan elektronik sudah dikenal sejak lama. Evolusi dokumentasi dari kertas ke format elektronik bertujuan untuk selalu meningkatkan komunikasi, mengurangi kesalahan dan memfasilitasi kesinambungan perawatan. Idealnya ketika perbaikan untuk catatan keperawatan dipikirkan, mereka harus mempertimbangkan kebutuhan perawat, dampak alur kerja fungsional baru dan kesesuaian dengan model gambaran dari data standar yang khusus untuk praktik kerja mereka (Schachner et al., 2016). Penggunaan teknologi informasi dalam perawatan kesehatan adalah fitur utama dari sebagian besar rekomendasi. Melalui catatan keperawatan elektronik, dapat dilakukan asuhan yang komprehensif dan memiliki pelayanan yang bervariasi dalam catatan keperawatan seperti "aktivitas pencegahan jatuh" dan "pemeriksaan kondisi pasien" (Lee \& Yu, 2018).

Tahap lanjut penerapan catatan kesehatan elektronik menunjukkan hasil penting, dari lama tinggal pasien (prolonged length of stay) dan penerimaan kembali pasien di rumah sakit. Terbukti bahwa hubungan antara lingkungan kerja keperawatan, kualitas asuhan keperawatan dan kepuasan pasien menjadi lebih baik karena teknologi diintegrasikan ke dalam praktik. (Hessels, Flynn, Cimiotti, Bakken, \& Gershon, 2015). Proses keperawatan di era modern saat ini menjadi tuntutan bagi perawat dari berbagai aspek. Perawat harus melakukan proses keperawatan berdasarkan standar asuhan keperawatan. Sistem dokumentasi yang berbasis teknologi informasi akan membantu dalam memenuhi standar dan kualitas dokumentasi, memudahkan dalam pengambilan keputusan, menyediakan informasi yang mudah di akses, dapat meminimalkan potensi kehilangan atau kerusakan dari catatan perkembangan, meningkatkan pertukaran informasi dan koordinasi antara perawat atau tim kesehatan lain, dokumentasi dapat 
mudah diaudit, membantu meningkatkan akurasi data klien, dapat mengakses kemajuan perkembangan kesehatan klien serta mengurangi biaya perawatan sehingga dapat meningkatkan kualitas pelayanan perawatan (Sulastri \& Sari, 2018).

Catatan keperawatan elektronik digambarkan sebagai praktik terbaik saat ini, baik dalam hal sistem, maupun keterlibatan dan kontribusi perawat dan profesional kesehatan lainnya terhadap sistem tersebut. Pendekatan yang digunakan dalam pengembangan sistem seperti pemantapan dasar informatika dengan nuansa yang berbeda, komitmen, keterlibatan dan partisipasi perawat (Hardiker, Dowding, Dykes, \& Sermeus, 2019). Semua agen layanan kesehatan diharapkan memiliki pendokumentasian elektronik dalam waktu dekat untuk memastikan keamanan dan dokumentasi perawatan yang lebih baik. Untuk banyak alasan, perpindahan ke catatan layanan kesehatan tanpa kertas adalah usaha yang menakutkan dan mahal bagi lembaga layanan kesehatan, dan tidak semua orang antusias dengan penggunaan pendokumentasian elektronik.

Meskipun dokumentasi keperawatan elektronik memiliki banyak manfaat, tetapi pada implementasinya menimbulkan beberapa masalah, karena setiap perubahan dalam sistem kerja memiliki konsekuensi penting bagi perawat maupun pasien (Chand, 2014). Perawat mengidentifikasi banyak tantangan dalam melakukan pencatatan pada rekam medis elektronik yang berhubungan dengan pengetahuan dan sikap positif untuk teknologi informasi dan komunikasi (O'Mahony et al., 2014). Sebagian besar studi menunjukkan bahwa untuk menggambarkan keadaan umum pasien pada individu dan kelompok menjadi sulit ketika menggunakan catatan kesehatan elektronik. Laporan singkat dan alat handoff dalam catatan kesehatan elektronik terbukti tidak cukup untuk mendukung pekerjaan perawat sepanjang shift, dan selama handoff, sehingga mereka bergantung pada formulir kertas yang dibuat sendiri.

Perawat membutuhkan alat yang dapat memfasilitasi kemampuan mereka secara individu dan konteks informasi yang bermakna secara klinis (Wisner, Lyndon, \& Chesla, 2019). Reformasi teknologi informasi dalam bidang kesehatan saat ini, mewajibkan Rumah Sakit menerapkan sistem catatan kesehatan elektronik untuk memfasilitasi berbagai data dan kerjasama di antara penyedia layanan kesehatan, sehingga dapat meningkatkan kualitas perawatan dan efisiensi dalam sistem pelayanan kesehatan (De Pietro \& Francetic, 2018). Peraturan dan kebijakan pemerintah tentang teknologi informasi kesehatan menyebabkan 
perubahan skala besar dari catatan kertas ke sistem catatan kesehatan elektronik, dengan tujuan untuk mengelola dan memanfaatkan data pasien dengan lebih baik, mengurangi biaya, dan meningkatkan efisiensi di seluruh sistem pelayanan kesehatan (Taneja, 2018). Kompleksitas pengambilan keputusan di antara para penyedia perawatan memerlukan kepercayaan diri dalam menggunakan teknologi, melalui pendekatan tim interprofesional, penilaian dan perawatan pasien (Kanaskie \& Snyder, 2018).

Selain itu, untuk menunjang hal tersebut diperlukan manajer keperawatan yang memiliki pengetahuan yang luas dalam bidang informatika, untuk dapat mempengaruhi dan mengolah data yang dikumpulkan, serta memastikan bahwa perawat professional berkontribusi untuk merawat pasien dalam lingkungan yang dinamis, sehingga meningkatkan komunikasi yang efektif antar pemberi pelayanan di rumah sakit. (Tariq et al., 2018). Pada tingkat eksekutif, peran kepala perawat informasi menjadi sangat penting. Perawat tersebut bertanggung jawab untuk mengarahkan pemimpin, penerapan, visi strategis, dan transformasi menyeluruh dalam penggunaan data dan informasi untuk perawatan berkualitas dalam organisasi kesehatan. Dalam hal ini termasuk pemilihan, perencanaan, desain, pembangunan, pengujian, implementasi, pemeliharaan, dan evaluasi keseluruhan sistem catatan kesehatan elektronik dan sistem informasi klinis lainnya. Dukungan dan kesadaran yang tinggi, dapat memfasilitasi pengguna untuk meningkatkan kualitas pelayanan, yang pada akhirnya akan menumbuhkan keinginan pengguna untuk terus menggunakan sistem ini, untuk meningkatkan kualitas pelayanan, dan keberhasilan penerapannya (Kuo, 2018). Pemahaman sikap yang mendalam dan dukungan dari seluruh tingkatan sangat diperlukan, karena dapat berpengaruh terhadap penerapan sistem pencatatan kesehatan elektronik (Entzeridou et al., 2018). Meskipun terdapat tantangan dan faktorfaktor yang menghambat penerapan catatan kesehatan berbasis elektronik, tetapi penggunaan sistem ini merupakan cara terbaik untuk menghadapi tantangan baru dan perubahan kebutuhan perawatan kesehatan saat ini (Chand, 2014).

Dokumentasi ini melaporkan kondisi aktual pasien sehingga mempercepat tim kesehatan dalam mengambil keputusan yang tepat dalam memberikan perawatan pasien dan menetapkan prioritas serta memutuskan perawatan yang sesuai dengan intervensi. Selanjutnya data yang terkumpul disimpan dalam database sebagai bukti tertulis tentang kemajuan pasien. Komite Praktik Keperawatan merekomendasikan konsistensi dalam prosedur perawatan berbasis bukti, yang terdiri dari datapasien dan data-data rencana strategi, di dalam dan pada akhirnya di seluruh 
situasi perawatan. Jika perawat atau ahli perawat menggunakan sumber daya mereka dan tidak mampu memanfaatkan secara maksimal, seperti tidak mampu menerapkan sesuai dengan kemampuan yang seharusnya dimiliki oleh perawat yang mampu menggunakan pendokumentasian elektronik. Dengan demikian perawat akan merasa nyaman menjalankan pekerjaannya.

\section{Manfaat Dokumentasi Keperawatan Elektronik}

Suatu studi diselenggarakan di University Medical Center Heidelberg selama 18 bulan. Hasil dari studi menunjukkan adanya suatu peningkatan yang penting tentang kwantitas dan kwalitas dokumentasi. Aspek positif meliputi kelengkapan dari dokumentasi keperawatan. Aspek yang formal dan peningkatan kwalitas hubungan antar perawat. Aspek yang negatif adalah berkaitan dengan contens dari rencana keperawatan (Cornelia, et al ,2007). Electronik health Record dilaporkan memiliki manfaat sebagai berikut

1. Penghematan biaya dari penggunaan kertas untuk pencatatan.

2. Tidak perlu gudang yang besar dalam penyimpanan arsip.

3. Penyimpanan data (Record) pasien menjadi lebih lama.

4. EHR yang dirancang dengan baik akan mendukung ototnomi yang dapat dipertanggung jawabkan.

5. Membantu dalam mencari informasi yang cepat sehingga dapat membantu dalam pengambilan keputusan yang cepat.

6. Meningkatkan produktivitas bekerja.

7. 7.Mengurangi kesalahan dalam menginterprestasikan pencatatan. (Gurley L, Advantages and Disadvantages of the Electronic Medical Record)

- Sedangkan menurut Holmas (2003, dalam Sitorus 2006) terdapat beberapa keuntungan utama dari dokumentasi berbasis komputer yaitu:

1. Standarisasi, terdapat pelaporan data klinik yang standar yang mudah dan cepat diketahui;

2. Kualitas, meningkatkan kualitas informasi klinik dan sekaligus meningkatkan waktu perawat berfokus pada pemberian asuhan;

3. Accessibility legibility, mudah membaca dan mendapat informasi klinik tentang semua pasien dan suatu lokasi. 


\section{PENUTUP}

Dokumentasi keperawatan yang berbasis teknologi IT sangat diperlukan di era modern saat ini disamping dapat memberikan keakuratan data kepada klien serta perencanaan untuk megahasilkan kualitas dan kinerja perawat dalam melakukan asuhan keperawatan yang baik. Sebagai pelaksana pelayanan kesehatan, rumah sakit juga sangat terbantu dengan adanya sistem dokumentasi keperawatan secara elektronik karena dapat menyediakan akses yang cepat dalam memberikan informasi, meminimalkan potensi kehilangan atau informasi yang rusak, menekan anggaran biaya yang dikeluarkan. Dapat mengurangi resiko kesalahan dalam melakukan intervensi, membantu dalam memenuhi pertanggungjawaban dokumentasi melalui akurasi informasi dan data pasien, memudahkan data epidemiologi, meningkatkan komunikasi dalam pertukaran informasi serta koordinasi diantara perawat dan anggota tim kesehatan lainya, meningkatkan keselamatan pasien dengan mengurangi kesalahan medis (John et al, 2016). 


\section{DAFTAR PUSTAKA}

Dalami, E. (2011). Dokumentasi Keperawatan Dengan Kurikulum Berbasis Kompetensi. Jakarta : Trans Info Media

Dewi, Asra. (2019). Dampak Penerapan Sistem Pencatatan Keperawatan Elektronik. SURYA Vol. 11, No. 03

Efendy, M. (2012). Perbedaan Tingkat Kualitas Dokumentasi Proses Keperawatan Sebelum Dan Sesudah Penerapan NANDA-I, NIC, Dan NOC. Jurnal Keperawatan Soedirman, 7(2), 67-77.

Hickey, A., Gleeson, M., \& Kellett, J. 2012. READS: the rapid electronic assessment documentation system. British Journal of Nursing, 21(22), 1333-1339.

Ivo, G., Manik, M., \& Simamora, O. (2018). Pengalaman perawat dalam melakukan pengkajian pasien baru di satu rumah sakit swasta di indonesia bagian barat. Nursing Current . 6(1), 29-31.

John, S. K., \& Bhattacharya, C. 2016. Documentation guidelines based on expectation of documentation helps accurate documentation among nurses in psychiatric settings. Asian Journal of Nursing Education and Research, 6(2), 260.

Nokes, Kathleen M., Aponte, Judith, Nickitas, Donna M., Mahon, Pamela Y., Rodgers, Betsy, Reyes, Nancy, . . . Dornbaum, Martin. 2012. Teaching Home Care Electronic Documentation Skills to Undergraduate Nursing Students. Nursing Education Perspectives, 33(2), 111-115.

Priharjo, Robert (2012). Pengkajian Fisik Keperawatan: konsep, proses dan praktek. Volume 2. Edisi 4. Jakarta : EGC

Sari, D. P., \& Siwi, G. R. (2019). Hubungan Antara Pengetahuan Perawat Tentang Rekam Medis dan Dokumentasi Keperawatan Dengan Kelengkapan Pencatatan Dokumentasi Keperawatan di Klinik MTA Surakarta 2019. Infokes Journal, 9(1), 45- 49.

Simamora, R. (2009). Dokumentasi Proses Keperawatan.

Simamora, R. (2009). Dokumentasi Proses Keperawatan.

Simamora, R. H., Purba, J. M., Bukit, E. K., \& Nurbaiti, N. (2019). Penguatan Peran Perawat Dalam Pelaksanaan Asuhan Keperawatan Melalui Pelatihan Layanan Prima. JPPM (Jurnal Pengabdian Dan Pemberdayaan Masyarakat), 3(1), 25-31.

Sulastri. dkk. (2018). Metode pendokumentasian dalam meningkatkan kualitas pelayanan kesehatan Jurnal Kesehatan, 9.( 3) 